\title{
Method: low-cost delivery of the cotton leaf crumple virus-induced gene silencing system
}

\author{
John Richard Tuttle ${ }^{1 *}$, Candace H Haigler ${ }^{1,2}$ and Dominique Robertson ${ }^{2}$
}

\begin{abstract}
Background: We previously developed a virus-induced gene silencing (VIGS) vector for cotton from the bipartite geminivirusCotton leaf crumple virus (CLCrV). The original CLCrV VIGS vector was designed for biolistic delivery by a gene gun. This prerequisite limited the use of the system to labs with access to biolistic equipment. Here we describe the adaptation of this system for delivery by Agrobacterium(Agrobacterium tumefaciens). We also describe the construction of two low-cost particle inflow guns.

Results: The biolistic CLCrV vector was transferred into two Agrobacterium binary plasmids. Agroinoculation of the binary plasmids into cotton resulted in silencing and GFP expression comparable to the biolistic vector. Two homemade low-cost gene guns were used to successfully inoculate cotton (G. hirsutum) and N. benthamiana with either the CLCrV VIGS vector or the Tomato golden mosaic virus (TGMV) VIGS vector respectively.

Conclusions: These innovations extend the versatility of CLCrV-based VIGS for analyzing gene function in cotton. The two low-cost gene guns make VIGS experiments affordable for both research and teaching labs by providing a working alternative to expensive commercial gene guns.
\end{abstract}

Keywords: Cotton, VIGS, Virus-induced gene silencing, Cotton leaf crumple virus, Agroinoculation, Particle inflow gun, Bombardment, Gossypium

\section{Background}

Virus-induced gene silencing (VIGS) is a reverse genetics technique that exploits the plant's post-transcriptional gene silencing (PTGS) machinery to obtain a sequencespecific transcript reduction for a targeted gene [1,2]. The technique employs a virus that has been modified to carry a fragment of a host gene. When the virus infects the plant, it triggers PTGS against the viral genome as well as the included host sequence. This leads to the degradation of RNAs with homology to the viral genome and produces a knockdown phenotype for the targeted gene(s). Because it can rapidly silence genes without the need for stable transformation, VIGS has become an attractive alternative to other reverse genetics strategies, which are timeconsuming and especially difficult in plant species like cotton that are recalcitrant to transformation/regeneration.

VIGS vectors have been developed from a variety of virus/host combinations [1-3]. Although vectors have

\footnotetext{
* Correspondence: jrtuttle@ncsu.edu

'Department of Crop Science, North Carolina State University, Raleigh, NC 27695, USA

Full list of author information is available at the end of the article
}

been constructed from RNA and DNA viruses as well as viral DNA satellites, we will only focus on vectors used in this research as derived from the bipartite DNA viruses of the family Geminiviridae, genus Begomovirus. These are single stranded DNA viruses with a conserved, well-characterized genome organization. The two genome components are designated DNA A and DNA B. Sequences coding for replication and movement proteins are split between the A and B components, respectively [4]. The A component contains 5 predicted open reading frames that code for the replication related proteins AL1 and AL3, the transactivator/anti-silencing protein AL2, the putative silencing suppressor AL4, and the coat protein AR1. The B component contains two open reading frames that code for the intercellular and intracellular movement proteins, BL1 and BR1 respectively. The two components share a $\sim 200$-bp region of high homology [4] referred to as the common region, which contains the origin of replication and a consensus sequence that is cleaved and ligated by the AL1 protein during rolling circle replication $[5,6]$. When a common region is placed on either side of the genome as a direct repeat, the

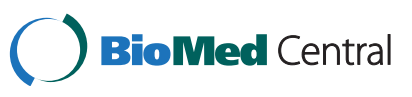


region between the replication origins is released in planta to form a functional viral episome $[7,8]$.

To accommodate targeting sequences, a multiple cloning site is typically inserted either in place of the $A R 1$ sequence or downstream of the $B R 1$ gene [9-12]. Peele and coworkers reported that the latter approach resulted in more extensive silencing, but insertion of sequences downstream of the CLCrVBR1 gene failed to result in a systemic infection [9], [Tuttle and coworkers, unpublished]. The deletion or replacement of $A R 1$ sequence renders begomoviruses non-transmissable by their whitefly vector $[13,14]$. Therefore, to achieve VIGS the viral vector must be introduced into the plant cells either mechanically or through the use of Agrobacterium vectors.

Particle bombardment employs a "gene gun" to blast particles coated with viral DNA into the plant. The gene gun can be commercial (BioRad's Helios or PDS-1000) or a homemade particle inflow gun (PIG; [15]). Both are powered by pressurized helium. A solenoid valve on the gas cylinder controls the rapid release of helium, which passes into a vacuum chamber through a filter holding micron or submicron particles of gold or tungsten that carry the nucleic acids. The metal particles are then forced into the samples below the filter [15]. Although there have been several publications detailing the construction of homemade gene guns, some degree of technical skill is required for their construction. This together with the high cost of commercial gene guns means that VIGS vectors that rely on biolistic delivery methods are not useful in all labs [15-17].

There are two other relatively easy and inexpensive methods for inoculating begomovirus vectors: DNA abrasion and agroinoculation. DNA abrasion involves the use of an abrasive (carborundum or ground glass) to introduce a viral DNA solution into leaf cells [18]. Although this method of inoculation is reasonably efficient for viruses that are not phloem-limited, it is not effective for all virus/host combinations, including Cotton leaf crumple virus (CLCrV)/cotton, the combination described here. The success of this method depends in part on the tissue specificity of the virus as well as the mechanical properties of the host leaf being inoculated $[18,19]$. For inoculation using Agrobacterium [20], similar to biolistic vectors, each component of the vector must be flanked by directly repeated common regions. For bipartite begomoviruses, a mixture of Agrobacterium carrying the A and B component plasmids is introduced into the plant through stem inoculation, wounding, or infiltration into intercellular leaf spaces [20-22]. In each of these methods, a single unit-length viral genome component is released from plasmid DNA to establish a systemic infection.

Cotton leaf crumple virus (CLCrV) is a cotton-infecting geminivirus endemic to the southwestern United States and Mexico [23]. Because it is a vascular-associated virus $[12,24]$ it is more difficult to inoculate than other begomoviruses that show broader tissue specificity [19]. We developed the A DNA as a vector for foreign DNA by replacing the coat protein gene with a multiple cloning site and demonstrated VIGS in cotton (Gossypium hirsutum) [12]. Co-bombardment of cotyledons with the modified A DNA and wild type B-DNA produced systemic silencing in several G. hirsutum cultivars that persisted throughout the plant for over a year and was most extensive in the cultivars Acala SJ-1 and Deltatype Weber [25]. VIGS was visualized using a 500-bp fragment of the chlorophyll biosynthetic gene, Magnesium Chelatase subunit I (Chll). Silencing of this gene produced a sectored pattern of chlorophyll loss that was more extensive at lower growth temperatures [12]. We also showed that CLCrV could be used as an expression vector by inserting a full-length GFP in place of the coat protein gene [12].

In this paper, we expand the potential of cotton VIGS by: (a) demonstrating the effectiveness of CLCrV VIGS vectors after moving them into binary vectors for agroinoculation and (b) providing instructions for making two inexpensive gene guns and demonstrating their potential for inoculating VIGS vectors.

\section{Results and discussion}

\section{Binary vectors for Agrobacterium-mediated delivery of CLCrV}

Many labs lack the necessary equipment to inoculate the biolistic form of the CLCrV vector. To address this, we cloned each of the vector's components into the opensource binary plasmid, pCambia1300 (CAMBIA, Canberra, Australia). The A-DNA vector, pJRT.Agro. CLCrVA.008 (referred to as CLCrVA:CP-), contains a multiple cloning site in place of the coat protein gene and produces an episome that is identical to that from the biolistic vector following inoculation. Episomes from the B-DNA binary plasmid, pJRT.Agro.CLCrVB1.3 (referred to as CLCrVB), are also identical to their biolistic counterpart. Two additional A-DNA plasmids, one for silencing ChlI (pJRT.Agro.CLCrVA.009) and one expressing GFP (pJRT.Agro.CLCrVA.010), were made by swapping XbaI/SacI fragments consisting of the 3 ' region of the $A L 1$ gene, $A L 2, A L 3$, the multiple cloning site, and one of the two duplicated common regions with the same region from the biolistic vector (Figure 1). These plasmids will be referred to as CLCrVA:ChlI and CLCrVA:GFP, respectively. Binary plasmids were transformed into the Agrobacterium strain GV3101:pMP90 [26] using the freeze-thaw method [27]. The plasmid pMP90 was derived from the pTiC58 plasmid pGV2201 and contains a deleted T-DNA region, the necessary virulence functions, and gentamycin resistance [26]. 


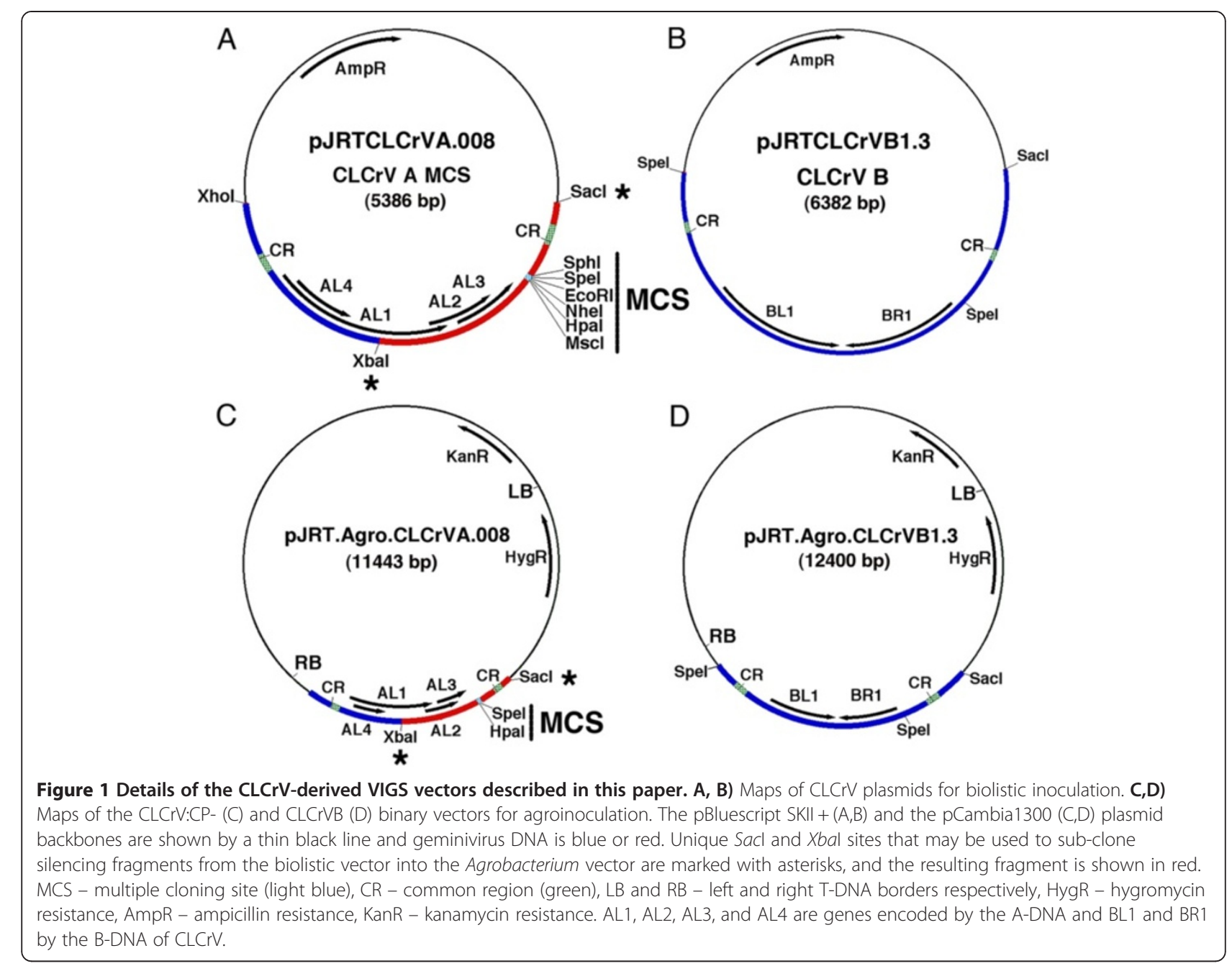

We used CLCrVA:ChlI to compare the efficiency and extent of silencing from the biolistic and Agrobacteriumbased methods of delivery. Cotton seedlings were agroinoculated by infiltration of the bottom surface of the cotyledons with a 1-ml syringe lacking a needle. The inoculum consisted of 1:1 mixtures of Agrobacterium cultures harboring CLCrVA:ChlI or CLCrVB. Following infiltration, theChlI silencing phenotype of leaf yellowing was first observed at 12 to 20 days post inoculation (dpi). Both particle bombardment and agroinoculation methods resulted in similar silencing efficiencies (Figure 2).We obtained an average inoculation efficiency of $81 \%(n=30)$ over three agroinoculation experiments, which was not significantly different from the $69 \%$ efficiency we observed for three biolistic experiments $(n=27$; p-value 0.34; two-tailed non-parametric t-test). Both the onset and extent of ChlI silencing after agroinoculation were similar to plants inoculated by particle bombardment (Figure 3). Similarly, the expression of solublemodified red-shifted GFP (smRS-GFP) [28] from the

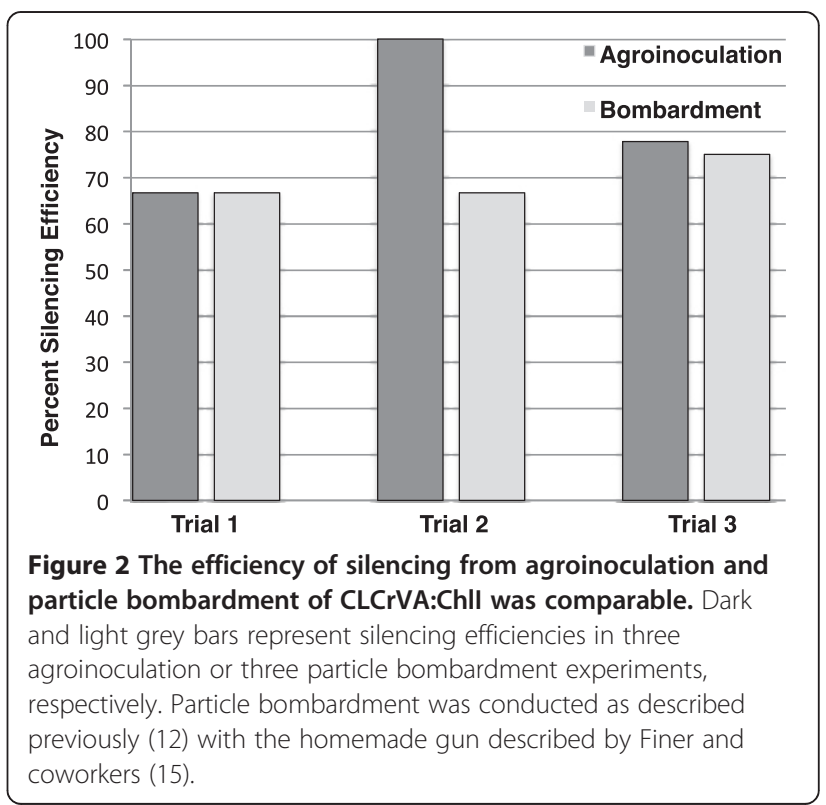


Agrobacterium vector CLCrVA:GFP was also comparable to particle bombardment. As described previously [12], GFP fluorescence was confined to vascular associated cells, reflecting the known tissue specificity of CLCrV (data not shown).

The biolistic vector has 6 different unique restriction sites in its MCS but, due to its larger size, only two of these sites are unique in the Agrobacterium vector. This makes cloning silencing fragments into the Agrobacterium vector more difficult. To overcome this, silencing fragments can be introduced into the biolistic CLCrV A vector and then sub-cloned into the Agrobacterium vector using SacI and XbaI (Figure 1). Although not in the MCS, the SacI and XbaI sites occur only once in both of the $\mathrm{CLCrV}$ A vectors.

One minor drawback of agroinoculation was that initial seedling growth was slightly delayed compared to their biolistic counterparts for both ChlI silencing and GFP expression constructs. This difference occurred despite the production of identical viral episomes in both cases. The transient slower growth of agroinoculated plants was consistent with native Agrobacterium acting as a plant pathogen [29] and causing systemic changes in inoculated plants [30].

\section{Development of low-cost particle inflow guns}

As an alternative to commercial particle bombardment systems, a 5-dollar pump-action plastic water gun can serve as a gene gun (Figure 4A,B). The only modifications required were the removal of a small plastic tip covering the outlet nozzle, and cutting of the outlet nozzle to match the outer diameter of a Millipore swinex syringe filter, used to hold the DNA-coated particles (Figure 4B). The gun employed a small hand-powered pump to charge a cylinder with compressed air, which was then released to travel through the filter tip so that the 1-micron gold particles carrying the VIGS vectors were propelled into the target cells. At least one comparatively simple gene gun has been described previously [17], but required the use of a separate compressed air supply.

This gun was used to inoculate cotton with the biolistic CLCrV-based VIGS vector carrying a 500-bp fragment of the ChlI gene. The number of pump strokes was used to gauge pressure in the gun, and 40 to 60 strokes resulted in successful inoculation of the CLCrV silencing vector. Inoculation efficiency was visually assessed by counting the number of plants showing photobleaching. In a preliminary experiment, silencing
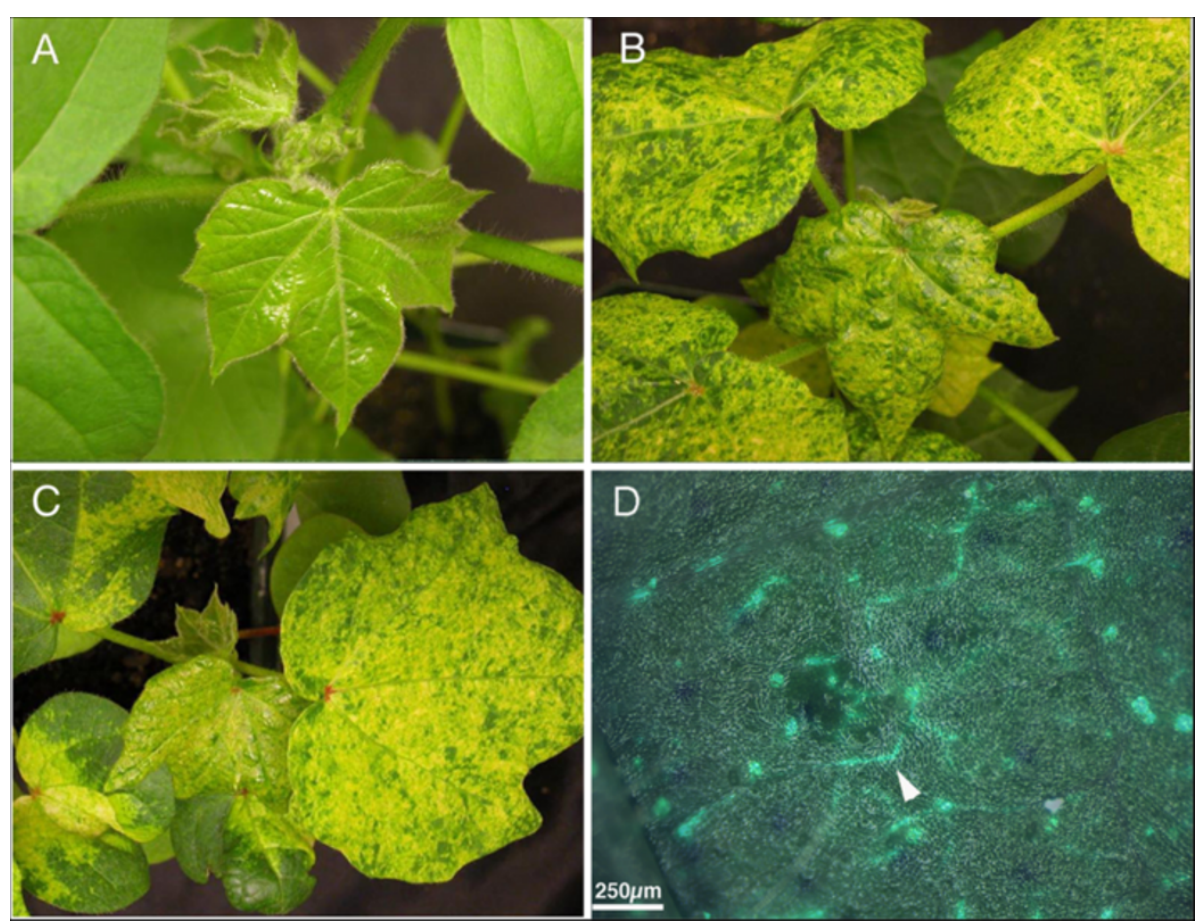

Figure 3 Silencing and expression from the CLCrV Agrobacterium vector was comparable to the biolistic vector. A) New growth on cotton plants agro-inoculated with the CLCrVB and CLCrV:CP- lacked visible symptoms at $35 \mathrm{dpi}$. B) New growth on cotton plants agro-inoculated with CLCrVB and CLCrVA:Chll showed a sectored loss of chlorophyll throughout the leaf at $35 \mathrm{dpi}$. C) Plant bombarded with the biolistic form of the vector used in (B) showed a similar pattern of silencing as the plant shown in (B) at 38 dpi. D) Overlay of GFP and brightfield images showed vein-delimited GFP expression (white arrowhead) in new growth of plants agro-inoculated with CLCrVB and CLCrVA:GFP at 28 dpi. 


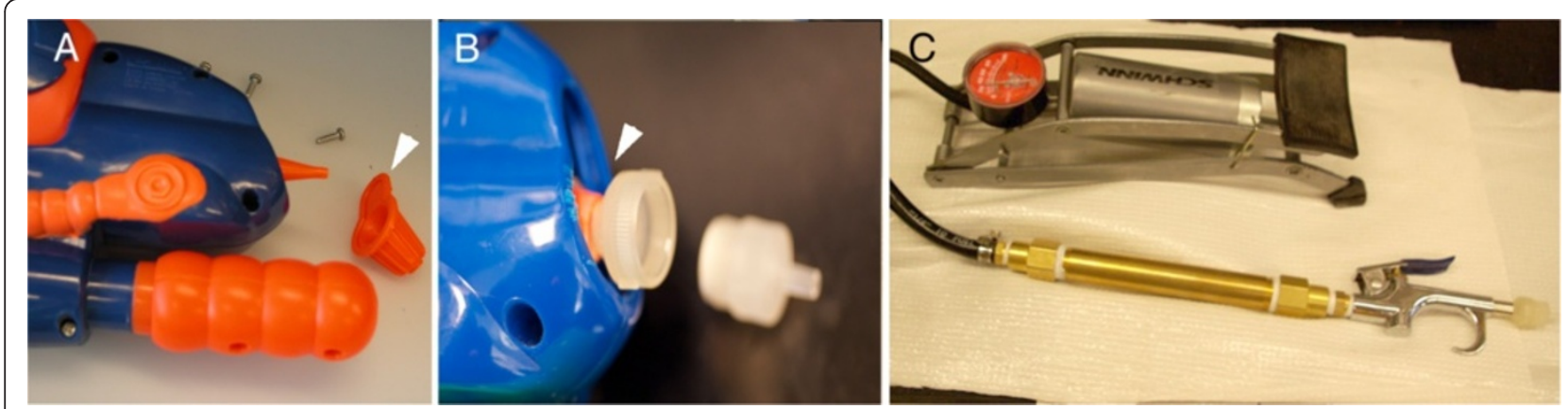

Figure 4 Examples of two homemade gene guns. A, B) A plastic gene gun made from a slightly modified 5-dollar water gun. A) The only modification required was to connect a Millipore swinex filter tip to the nozzle for compressed air. This was achieved by removing three screws in the plastic body, followed by the plastic nozzle cover (arrow). B) The $\$ 5$ gene gun with the filter tip screwed into the cut-off nozzle (arrow). C) An example of a metal gene gun built for approximately $\$ 50$ from parts at a local hardware store (see Materials and Methods for construction details).

was observed in 1 of 3 inoculated cotton plants, but in a subsequent experiment silencing was observed in 3 of 6 inoculated cotton plants (Figure 5A). More plants can be inoculated to compensate for the relatively low inoculation efficiency with this simple gene gun. The extent of silencing (yellow leaf area) was similar to plants inoculated by other methods.

Although it was useful, the modified water gun did not withstand the rigorous cleaning needed to conduct sterile bombardments. Therefore, we developed a more durable version of the gun from off-the-shelf parts purchased at a hardware store for approximately 50 dollars. Most of the cost was attributable to the brass components. The metal gun was used to introduce principles of gene silencing to students in a biochemistry lab. In these experiments both wild type and Tomato golden mosaic virus (TGMV)-derived VIGS vectors were inoculated into Nicotian abenthamiana. Efficiency was assessed with either photobleaching from the TGMV silencing vector carrying a 156-bp ChlI fragment (TGMVB:ChlI [9]) or symptom development (contorted leaves) from the wildtype virus. The built-in gauge on the bicycle pump was used to measure pressure in the gun. A pressure of $80 \mathrm{lb} /$ in $^{2}$ was sufficient to obtain silencing in 3 of 5 inoculated plants and to produce TGMV infection in 5 of 5 inoculated plants (Figure 5B,C).

\section{Conclusions}

Tools for several affordable methods for the delivery of the CLCrV VIGS vector have been developed and demonstrated. The new molecular tools were binary plasmids for agroinoculation of the CLCrV cotton VIGS vector by syringe infiltration. Agroinoculation resulted in essentially equivalent efficiency and extent of silencing compared to biolistic inoculation. The Agrobacteriumvectors were larger than the biolistic VIGS vectors and thus contain fewer unique restriction sites for cloning in silencing fragments, but the ability to sub-clone fragments from the biolistic vectors circumvents this problem. The new hardware consisted of two low-cost
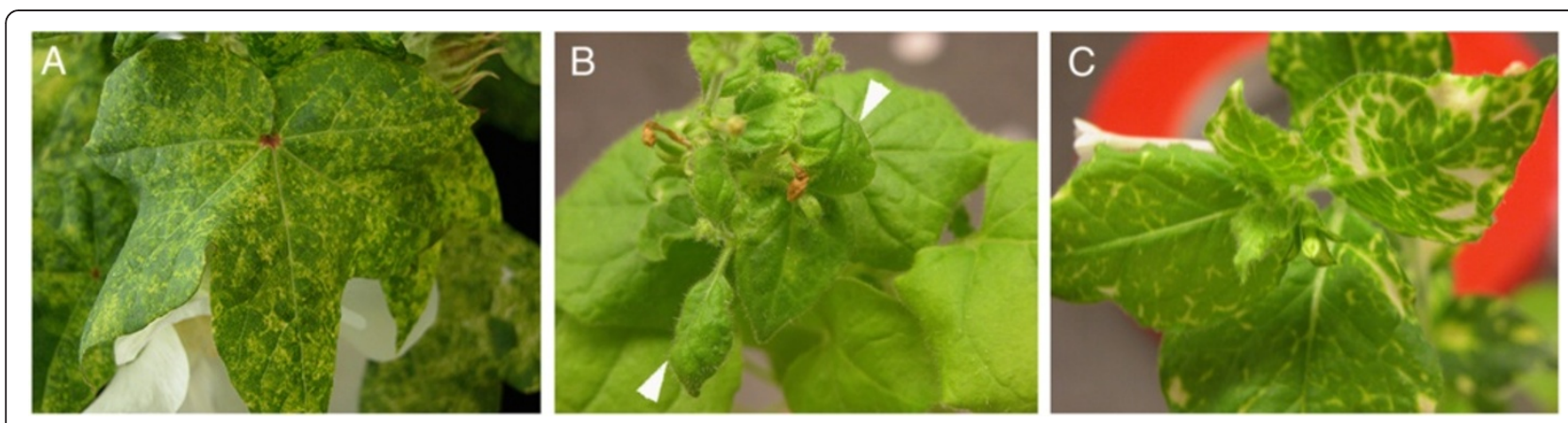

Figure $\mathbf{5}$ Chl Isilencing from two different VIGS vectors inoculated using two low-cost particle inflow guns. A) Chll silencing in cotton (64 dpi) co-bombarded with the CLCrVA:Chll and CLCrVB plasmids using the modified plastic water gun shown in Figure 4A,B. B) N. benthamiana (37 dpi) showing the viral symptom of contorted upper leaves (arrows) after bombardment with the wild type TGMV virus using the homemade metal gene gun. C) N. benthamiana (37 dpi) showing Chll silencing after co-bombardment with TGMVA and TGMVB:Chll using the metal gene gun (Figure 4C). 
(\$5 - \$50) particle inflow gunsmade exclusively from offthe-shelf components that can be used instead of expensive commercial devices for biolistic inoculation. The $\$ 50$ gene gun is durable and withstands rigorous cleaning while also being easy to construct and use. These simple and affordable biolistic guns will extend the potential for research and teaching based on VIGS.

\section{Methods}

\section{Vector availability}

All CLCrV vectors described here are available for nonprofit research from Addgene.org following a standard material transfer agreement.

\section{Plant material}

All cotton plants (G. hirsutum cv Deltapine 4515) were grown in a $25^{\circ} \mathrm{C} / 23^{\circ} \mathrm{C}$ (day/night) chamber at approximately $60 \%$ relative humidity under a bank of $16 \mathrm{VHO}$ T5 fluorescent lamps fixed at a height of 27 inches. Lighting $\left(135 \mu \mathrm{mol} \mathrm{s}{ }^{-1} \mathrm{~m}^{-2}\right.$ at the shelf level) was longday: 16 hours on, 8 hours off. Cotton plants were grown in 6-in diameter pots in Metromix 360 potting mix (Wyatt Quarles Seed Company, www.wqseeds.com), watered daily, and fertilized once per week with Miracle Grow $^{\circledR}$ (The Scotts Company LLC, www.scotts.com).

\section{Cloning the vector into pCambia}

To generate pJRT.Agro.CLCrVA.008, the biolistic empty vector plasmid pJRTCLCrVA.008 [12] was digested with $\mathrm{XbaI}$ and XhoI. A 1130-bp fragment from pJRTCLCrVA.008 containing one common region, AL4, and the 5' 664-bp of AL1 was ligated into pCambia1300 cut with XbaI and SalI to produce pJRT.Agro. CLCrVA.008.1. In a second digestion and ligation, pJRTCLCrVA.008 was cut with XbaI and SacI and the 1386-bp resulting fragment was cloned into pJRT.Agro. CLCrVA.008.1 cut with XbaI and $\mathrm{SacI}$ to generate a 11,443-bp plasmid pJRT.Agro.CLCrVA.008.

To produce the ChlI-silencing and GFP-expressing marker constructs pJRT.Agro.CLCrVA.009 and pJRT.Agro. CLCrVA.010, the biolistic constructs pJRTCLCrVA.009 and PJRTCLCrVA.010 were each digested with SacI and $\mathrm{XbaI}$ to release 1,883-bp and 2,062-bp fragments respectively. These fragments were then ligated into SacI, XbaI digested pJRT.Agro.CLCrVA.008 to produce pJRT.Agro. CLCrVA.009 and pJRT.Agro.CLCrVA.010.

Prior to inserting the $\mathrm{B}$ component of the viral genome into pCambia1300, it was necessary to reduce the duplication of B component sequence from a complete dimer [31] to a version with only one BR1 gene. This was accomplished by using PCR and the primers BDAgR1new (5' - ACC CAG ACT AGT AAA CGC TAT TAT ATA GG - 3') and BDAgF1 (5’ - GCG GAG CTC CAG AAC GAT CTC AGT TAG GTC ATG GG - 3’) to amplify a 906-bp fragment, containing a single common region, from the $\mathrm{CLCrV} B$ dimer. The BDAgF1 primer introduced a SacI restriction enzyme site at the 5' end of the PCR product. The additional SacI site was used in conjunction with an internal SpeI site to insert the 896bp fragment into the respective restriction sites of the pBluescript SK+II vector (Agilent Technologies, www. agilent.com) to create pJRTCLCrVB.1. Next, a 2,549-bp fragment was cut from the CLCrV B dimer using the restriction enzyme SpeI. This fragment contained a second viral common region as well as the two full-length open reading frames $B L 1$ and $B R 1$. The fragment was purified by gel extraction and ligated into the SpeI restriction site of pJRTCLCrVB.1. The resulting clones were screened for proper orientation of the insert by $\mathrm{XbaI}$ digestion and called pJRTCLCrVB1.3. The plasmid JRTCLCrVB1.3 contains two viral common regions that flank the two fulllength open reading frames $B L 1$ and $B R 1$ in the pBluescript SK+ II vector.

After construction of pJRTCLCrVB1.3, the construct was digested with the restriction enzymes HindIII and SacI. The 3,490-bp fragment produced from this digestion was cloned into the respective sites in the HindIII/SacI digested and dephosphorylated pCambia1300 plasmid to produce the 12,400-bp plasmid pJRT.Agro.CLCrVB1.3.

\section{Agroinoculation of the vector}

A. tumefaciens strain GV3101:pMP90 was first made competent by inoculating $50 \mathrm{ml}$ of Luria Bertani medium with $125 \mu \mathrm{L}$ of an overnight Agrobacterium culture. The $50-\mathrm{ml}$ culture was then grown at $30^{\circ} \mathrm{C}$ for 12 hours, spun for 10 minutes at $4000 \mathrm{x} \mathrm{rpm}$ to pellet cells, and washed in $5 \mathrm{ml}$ of sterile TE buffer; this step was repeated once. The TE buffer was removed and the cells were then resuspended in $5 \mathrm{ml}$ of Luria Bertani medium and $200-\mu \mathrm{L}$ aliquots were refrozen in liquid nitrogen.

For transformation, cell aliquots were thawed on ice, and $1 \mu \mathrm{g}$ of plasmid DNA was added to the cells on ice for 5 minutes. Next, the cells and DNA were transferred to liquid nitrogen for 5 minutes, then a $37^{\circ} \mathrm{C}$ water bath for 5 minutes. $1 \mathrm{ml}$ of Luria Bertani medium was added to the tube, and the cells were incubated at room temperature for 4 hours with agitation. The culture was spun down for 10 minutes at $4000 \mathrm{rpm}$ and all but approximately $100 \mu \mathrm{L}$ of the supernatant was removed. Cells were resuspended and then plated on Petri plates with $25 \mu \mathrm{g} / \mathrm{ml}$ each of kanamycin, rifampicin, and gentamycin and allowed to grow for 2 days at $30^{\circ} \mathrm{C}$.

The vector was introduced into cotton seedlings by infiltration. Cultures of each component were prepared as previously described [32]. After adjusting the density of each culture $\left(\mathrm{OD}_{600}\right.$ of 1.5$)$ and allowing them to incubate at room temperature in the dark for 4 hours without shaking, $\mathrm{A}$ and $\mathrm{B}$ component cultures were mixed in 
a 1:1 ratio and drawn up into a needleless 5-cc syringe. The mixture was introduced into cotton seedlings at the cotyledon stage by gently forcing the solution into the spongy mesophyll on the bottom surface of the cotyledon. As the infiltration solution moved through the cotyledon, it became noticeably darker, and infiltration was continued until the entire cotyledon was darkened.

\section{Construction of a low-cost particle delivery device}

To construct an extremely low cost particle delivery device, we first purchased a pump-action water gun; the MAX D 2000 (Hasbro Inc., Hasbrotoyspr@hasbro.com) from a local store for approximately 4 dollars. A small Phillips head screwdriver was used to remove three screws from the plastic housing on the front of the gun. This allowed the plastic housing to be pried open just enough for the plastic nozzle cover to be removed. The exposed conical nozzle of the gun was then modified to hold a $13 \mathrm{~mm}$ Millipore swinex filter tip (Millipore Inc., www.millipore.com). The plastic nozzle was cut back $(\sim 18 \mathrm{~mm})$ to the outer housing so that its inner diameter was large enough to allow for the insertion of the threaded filter tip. For inoculation, the built-in hand pump was pumped 40-60 times immediately prior to bombardment. No vacuum was used and the tip of the Millipore filter was placed less than a centimeter from the bottom surface of the cotyledon.

A second more durable gun was constructed consisting of a bicycle pump connected to one end of a brass cylinder via a section of 6 - $\mathrm{ft}$ fuel line with a $1 / 4$-in inner diameter. A blowgun was adapted to the other end of the brass cylinder and fitted with a 13-mm Millipore swinex tip. A bicycle pump with a pressure gauge rated up to $100 \mathrm{lb} / \mathrm{in}^{2}$ (Schwinn Inc., www.schwinn.com) was adapted to the fuel line using a $1 / 4$-in inflation nozzle (provided in a Kobalt 5-PC blowgun kit; Lowes Inc., www.lowes.com, Item \#001174). This was essentially a 1/1/4in threaded male fitting on one end and a barb on the other. The fuel line was secured to the barb using a \#4 pipe clamp (King Seal Fastener Technology Co., Ltd., Anhui, China, Item \#62508). The other end of the fuel line was connected to a brass $1 / 4$-in male barb adapter (Watts Industries Inc., www.watts.com, Item \#A-192) and was secured with a \#4 pipe clamp. The $1 / 4$-in male barb adapter was screwed into a female $1 / 4$-in to $1 / 2$-in brass coupling (Watts Industries Inc., Item \#A-813) that was threaded onto a $1 / 2$-in $X$ 6-in brass pipe nipple (Watts Industries Inc., Item \#LA-845). Another $1 / 4$-in to $1 / 2$-in female coupling was put in place at the other end of the brass pipe. This coupling was attached to a Kobalt blowgun via a $1 / 1$-in male brass nipple (Watts Industries Inc., Item \#A-875). The end of the blowgun was fitted with a blowgun adapter included in the above mentioned kit, and the Millipore swinex filter tip was threaded directly into this adapter. For inoculation of $N$. benthamiana with TGMV, the bicycle pump was pumped to approximately $80 \mathrm{lb} / \mathrm{in}^{2}$ and the trigger of the blowgun was quickly compressed with the tip of the Millipore syringe filter held less than $1 \mathrm{~cm}$ from the surface of the leaf.

For a schematic image of this gene gun see Additional file 1: Figure S1.

\section{Microcarrier preparation}

For particle bombardment, aliquots of $1 \mu \mathrm{m}$ gold particles (INBIO Gold, Victoria, AU, Catalog \#BD061) were prepared by suspending $60 \mathrm{mg}$ of gold powder in $1 \mathrm{ml}$ of $100 \%$ ethanol. Particles were pelleted by centrifugation for 10 seconds at $13,000 \mathrm{rpm}$. The supernatant was discarded and the particles were resuspended in $1 \mathrm{ml}$ of sterile water. The particles were pelleted by centrifugation and resuspended in sterile water two additional times. Following the final resuspension, 50- $\mathrm{ll}$ aliquots were transferred to $1.5 \mathrm{ml}$ microfuge tubes and stored at $-20^{\circ} \mathrm{C}$.

To precipitate viral DNA onto the gold particles, $5 \mu \mathrm{g}$ of each viral component was added to a $50-\mu \mathrm{l}$ aliquot and vortexed for 30 seconds. $50 \mu \mathrm{l}$ of $2.5 \mathrm{M} \mathrm{CaCl}_{2}$ was added and the tube was vortexed for 30 seconds. $20 \mu \mathrm{l}$ of $0.1 \mathrm{M}$ spermidine was added to the tube and the mixture was vortexed for 3 minutes. The particles were pelleted by centrifugation at $10,000 \mathrm{rpm}$ for 10 seconds. The supernatant was removed and discarded. The pellet was resuspended in $250 \mu \mathrm{l}$ of $100 \%$ ethanol by vortexing. The particles were again pelleted by centrifugation at $10,000 \mathrm{rpm}$ for 10 seconds and the supernatant was discarded. The pellet was resuspended in $65 \mu \mathrm{l}$ of $100 \%$ ethanol. $12 \mu \mathrm{l}$ of the particle suspension was loaded onto the center of the filter tip for bombardment (see Additional file 2: Figure S2).

\section{Additional files}

Additional file 1: Schematic image of metal gene gun. Image of a disassembled metal gene gun labeled with corresponding part numbers. Additional file 2: Close-up image of Millipore swinex filter tip. Close-up image of a disassembled Millipore swinex filter tip. The red arrow marks the placement of the microcarrier suspension.

\section{Abbreviations}

VIGS: Virus-induced gene silencing; CLCrV: Cotton leaf crumple virus; TGMV: Tomato golden mosaic virus; PTGS: Post-transcriptional gene silencing; PIG: Particle inflow gun; Chll: Magnesium chelatase subunit l; dpi: Days post infection; smRS-GFP: Soluble-modified red-shifted green fluorescent protein; CR: Common region; LB: Left border; RB: Right border.

\section{Competing interests}

The authors declare that they have no competing interests. 


\section{Authors' contributions}

JRT carried out the molecular cloning, test inoculations, developed the gene guns, and drafted the manuscript. $\mathrm{CHH}$ and DR helped to plan research and write the manuscript. All authors read and approved the final manuscript.

\section{Acknowledgements}

For research support, we thank Cotton Inc. (Cary, NC) and the National Science Foundation (grant number IOS1025947).

\section{Author details}

1Department of Crop Science, North Carolina State University, Raleigh, NC 27695, USA. ²Department of Plant Biology, North Carolina State University, Raleigh, NC 27695, USA.

Received: 23 April 2012 Accepted: 19 July 2012

Published: 1 August 2012

\section{References}

1. Burch-Smith TM, Anderson JC, Martin GB, Dinesh-Kumar SP: Applications and advantages of virus-induced gene silencing for gene function studies in plants. Plant J 2004, 39:734-746.

2. Carrillo-Tripp J, Shimada-Beltran H, Rivera-Bustamante R: Use of geminiviral vectors for functional genomics. Curr Opin Plant Biol 2006, 9:209-215.

3. Robertson D: VIGS vectors for gene silencing: many targets, many tools. Annu Rev Plant Biol 2004, 55:495-519.

4. Davies JW, Stanley J: Geminivirus genes and vectors. Trends Genet 1989 5:77-81.

5. Laufs J, Traut W, Heyraud F, Matzeit V, Rogers SG, Schell J, Gronenborn B: In vitro cleavage and joining at the viral origin of replication by the replication initiator protein of tomato yellow leaf curl virus. Proc Natl Acad Sci U S A 1995, 92:3879-3883.

6. Preiss $W$, Jeske $H$ : Multitasking in replication is common among geminiviruses. J Virol 2003, 77:2972-2980.

7. Rogers SG, Bisaro DM, Horsch RB, Fraley RT, Hoffmann NL, Brand L, Elmer JS, Lloyd AM: Tomato golden mosaic virus A component DNA replicates autonomously in transgenic plants. Cell 1986, 45:593-600.

8. Stenger DC, Revington GN, Stevenson MC, Bisaro DM: Replicational release of geminivirus genomes from tandemly repeated copies: evidence for rolling-circle replication of a plant viral DNA. Proc Natl Acad Sci U S A 1991, 88:8029-8033.

9. Peele C, Jordan CV, Muangsan N, Turnage M, Egelkrout E, Eagle P, HanleyBowdoin $L$, Robertson D: Silencing of a meristematic gene using geminivirus-derived vectors. Plant J 2001, 27:357-366

10. Turnage MA, Muangsan N, Peele CG, Robertson D: Geminivirus-based vectors for gene silencing in Arabidopsis. Plant J 2002, 30:107-114

11. Fofana IB, Sangare A, Collier R, Taylor C, Fauquet CM: A geminivirusinduced gene silencing system for gene function validation in cassava. Plant Mol Biol 2004, 56:613-624.

12. Tuttle JR, Idris AM, Brown JK, Haigler CH, Robertson D: Geminivirusmediated gene silencing from Cotton leaf crumple virus is enhanced by low temperature in cotton. Plant Physiol 2008, 148:41-50.

13. Briddon RW, Watts J, Markham PG, Stanley J: The coat protein of beet curly top virus is essential for infectivity. Virology 1989, 172:628-633.

14. Azzam O, Frazer J, de la Rosa D, Beaver JS, Ahlquist P, Maxwell DP: Whitefly transmission and efficient ssDNA accumulation of bean golden mosaic geminivirus require functional coat protein. Virology 1994, 204:289-296.

15. Finer JJ, Vain P, Jones MW, McMullen MD: Development of the particle inflow gun for DNA delivery to plant cells. Plant Cell Rep 1992, 11:323-328.

16. Vain PK, Keen N, Murillo J, Rathus C, Nemes C, Finer J: Development of the Particle Inflow Gun. Plant Cell, Tissue and Organ Culture 1993, 33:237-246.

17. Gal-On A, Meiri E, Elman C, Gray DJ, Gaba V: Simple hand-held devices for the efficient infection of plants with viral-encoding constructs by particle bombardment. J Virol Methods 1997, 64:103-110.

18. Ascencio-lbanez JT, Settlage SB: DNA abrasion onto plants is an effective method for geminivirus infection and virus-induced gene silencing. J Virol Methods 2007, 142:198-203.

19. Rojas MR, Hagen C, Lucas WJ, Gilbertson RL: Exploiting chinks in the plant's armor: evolution and emergence of geminiviruses. Annu Rev Phytopathol 2005, 43:361-394.
20. Elmer JS, Sunter G, Gardiner WE, Brand L, Browning CK, Bisaro DM, Rogers SG: Agrobacterium-mediated inoculation of plants with tomato golden mosaic virus DNAs. Plant Mol Biol 1988, 10:225-234.

21. Briddon RW, Mansoor S, Bedford ID, Pinner MS, Markham PG: Clones of cotton leaf curl geminivirus induce symptoms atypical of cotton leaf curl disease. Virus Genes 2000, 20:19-26.

22. Gao S, Qu J, Chua NH, Ye J: A new strain of Indian cassava mosaic virus causes a mosaic disease in the biodiesel crop Jatrophacurcas. Arch Virol 2010, 155:607-612

23. Brown JN, Nelson MR: Host range and vector relationships of Cotton leaf crumple virus. Plant Dis 1987, 71:522-524

24. Brown JN, Nelson MR: Geminate particles associated with cotton leaf crumple disease in Arizona. Phytopathology 1984, 74:987-990.

25. Idris AM, Tuttle JR, Robertson D, Haigler CH, Brown JK: Differential Cotton leaf crumple virus-VIGS-mediated gene silencing and viral genome localization in different Gossypiumhirsutum genetic backgrounds. Physiol Mol Plant Pathol 2010, 75:13-22.

26. Koncz CS, Schell J: The promoter of TL-DNA gene 5 controls the tissuespecific expression of chimaeric genes carried by a novel type ofAgrobacteriumbinary vector. Mol Gen Genet 1986, 204:383-396.

27. Hofgen R, Willmitzer L: Storage of competent cells for Agrobacteriumtransformation. Nucleic Acids Res 1988, 16:9877.

28. Davis SJ, Vierstra RD: Soluble, highly fluorescent variants of green fluorescent protein (GFP) for use in higher plants. Plant Mol Biol 1998, 36:521-528

29. Lacroix B, Vaidya M, Tzfira T, Citovsky V: The VirE3 protein ofAgrobacterium mimics a host cell function required for plant genetic transformation. EMBO J 2005, 24:428-437.

30. Veena, Jiang H, Doerge RW, Gelvin SB: Transfer of T-DNA and Vir proteins to plant cells byAgrobacteriumtumefaciens induces expression of host genes involved in mediating transformation and suppresses host defense gene expression. Plant J 2003, 35:219-236.

31. Idris AM, Brown JK: Cotton leaf crumple virusis a distinct western hemisphere begomovirus species with complex evolutionary relationships indicative of recombination and reassortment Phytopathology 2004, 94:1068-1074.

32. Burch-Smith TM, Schiff M, Liu Y, Dinesh-Kumar SP: Efficient Virus-Induced Gene Silencing in Arabidopsis. Plant Physiol 2006, 142:21-27.

doi:10.1186/1746-4811-8-27

Cite this article as: Tuttle et al:: Method: low-cost delivery of the cotton leaf crumple virus-induced gene silencing system. Plant Methods 2012 $8: 27$

\section{Submit your next manuscript to BioMed Central and take full advantage of:}

- Convenient online submission

- Thorough peer review

- No space constraints or color figure charges

- Immediate publication on acceptance

- Inclusion in PubMed, CAS, Scopus and Google Scholar

- Research which is freely available for redistribution 